\title{
One for the road: the determinants of the road fatalities in the European Union
}

\author{
Elena-Maria PRADA \\ Bucharest University of Economic Studies \\ elena.prada@csie.ase.ro
}

\begin{abstract}
Traffic fatalities are a severe problem. The European Commission estimated that one in four road accidents are related to alcohol consumption. It is also shown that alcohol changes perceptions and is reflected in the driver's reflexes. This study aims to determine the factors that lead to changes in the mortality rate due to car accidents. The dataset was retrieved from different official sources depending on the type of variable. For the time-invariant variables were used two official sources from which the drivers are informed with the main road rules from a certain country. Using the Arellano-Bover / Blundell-Bond linear dynamic panel-data estimation on 22 European Union countries between 2012 to 2018, the results showed that the road safety laws have a meaningful and significant impact on road fatalities. Alcohol legal limit has a positive impact on road fatalities, which shows that if the legal alcohol limit is non-zero, the road fatalities increase. Another important result is related to young people neither in employment nor in education and training (NEET), which directly influences road fatalities. This result shows the importance of investment in education. At the same time, the results underline the importance of investments in infrastructure, as the length of the highways increases leads to a decrease in road fatalities.
\end{abstract}

Keywords: road fatalities, driving age, alcohol legal limit, panel data, dynamic panel data estimation.

\section{Introduction}

Road fatalities are significant from different perspectives, mainly through their implications as they generate human costs and other costs with social impact as traffic delays, as well as costs with insurances and police (Ghadi et al., 2018).

Among the 27 EU countries, the number of traffic fatalities decreased in 2019 compared to 2010 (European Commission, 2019). Furthermore, COVID-19 lockdown substantially impacted decreasing road fatalities (European Transport Safety Council, 2020). Even though the number of road fatalities has decreased in recent years, it continues to be a public health problem with multiple implications both socially and economically (World Health Organization, 2009; Ghadi et al., 2018).

In this paper, the main focus is on the determinants of road fatalities from the macroeconomic perspective together with the legislation aspects related to the age of obtaining the driving licenses and the legal alcohol limit in the European Union countries. In the first part of the paper, a brief description of the literature is presented, focusing on the main findings related to variables of interest. Next, it describes the method and data retrieving for the purpose of the paper. In this study the Arellano-Bover/Blundell-Bond estimator, since some of the variables of interest are time-invariant variables and also, it is suitable for panels with few time observations.

The findings suggest that road safety laws may be subject to a reassessment, and also, the main decision-makers should consider investing in education and infrastructure. The last part of the paper concludes the results and brings suggestions for future decisions.

DOI: $10.2478 /$ picbe-2021-0022

(C) 2021 E. M. Prada, published by Sciendo.

This work is licensed under the Creative Commons Attribution 4.0 License. 


\section{Literature review}

Road accidents, in general, are typified by diverse determinants both in structure and in importance. Kopits and Cropper (2003) showed that demographic decline and road building generated a lower fatalities rate, but alcohol consumption contributes to a higher mortality rate.

According to the European Commission, one in four road fatalities are related to alcohol consumption (SafetyNet, 2009). Many authors studied alcohol consumption and its effects on drivers (Benson et al. 1999; Young and Likens, 2000; Mann et al., 2006; Thomas et al., 2013; Papalimperi et al., 2019).

Alcohol consumption is a risk not only for drivers but also for pedestrians and for others. The main effects of alcohol consumption are different depending on the level of consumption. For example, if the alcohol level is $0.2 \mathrm{~g}$ per liter, the drivers' reaction time will increase. If the alcohol level is $0.4 \mathrm{~g}$ per liter, a slowdown in mental abilities will set in (Missoni et al., 2018). Therefore, alcohol consumption comprises a number of side effects that significantly influence the ability to drive. Papalimperi et al. (2019) conducted a study on how road fatalities are related to alcohol consumption and the use of psychoactive drugs. The autopsy results over seven years showed that over $40 \%$ of the victims were under the influence of alcohol, and $18 \%$ were related to drug consumption. The effects of the alcohol consumption on the mental activity and brain are relevant in the context of road fatalities as well. Therefore, the previously mentioned results can be a starting point for considering the legal alcohol limit admissible in each country can directly determine the road fatalities.

Traffic regulations are even more important as the number of cars increased in the recent period (Yannis et al., 2011; Roșca, 2019). The results related to the impact of motorization rate on road fatalities are mixed. Roșca (2019) observed that there is no significant relationship between motorization rate and the number of people killed in road accidents. In contrast, Hamed et al. (2013) observed that the motorization rate contributes to the growth of road fatalities. Despite these conflicting results, the motorization rate can be a risk factor for road fatalities (Yannis et al., 2011).

Diverse factors determined the road accident among which the most important are the weather (Edwards, 1998), the human mistakes and human factors (Benson et al. 1999; Young and Likens, 2000; Man et al., 2006; Thomas et al., 2013; Papalimperi et al., 2019), but also those who are the policy-makers (Kopits and Cropper, 2003; Yannis et al., 2011). Even though there are many factors that can affect the road accidents and road fatalities as well, for the purpose of this paper the analysis focused on several important aspects related to macroeconomics and road safety laws.

\section{Data and method}

This paper is focused on the determinants of the mortality from road accidents considering two perspectives: firstly, it is to see how some economic factors influence road fatalities and, secondly, how the road legislation in force in each country is reflected in road mortality.

The data set consists of 22 European Union countries due to incomplete data: Austria, Bulgaria, Croatia, Cyprus, Czechia, Denmark, Estonia, Finland, France, Germany, Hungary, Ireland, Lithuania, Luxembourg, Netherlands, Poland, Portugal, Romania, Slovakia, Slovenia, Spain, and Sweden, over the period between 2012 and 2018. Consequently, the final dataset covers a period of only seven years.

For the purpose of the analysis, the variables employed are time-invariant variables and macro-economic variables, varying in time and space. All the variables are presented in Table no.1, together with a short description and the retrieval source. 
Table 1. Variables description

\begin{tabular}{|c|c|c|c|}
\hline Variable & $\begin{array}{l}\text { Measurement } \\
\text { unit }\end{array}$ & Definition & Data source \\
\hline $\begin{array}{l}\text { Rate of } \\
\text { persons } \\
\text { killed in car } \\
\text { accidents }\end{array}$ & $\begin{array}{l}\text { Per one } \\
\text { million } \\
\text { inhabitants }\end{array}$ & $\begin{array}{l}\text { This variable is the dependent variable } \\
\text { and it was computed by dividing the total } \\
\text { number of road fatalities to the } \\
\text { population of the respective country } \\
\text { reported to one million people. }\end{array}$ & Eurostat \\
\hline $\begin{array}{l}\text { Social } \\
\text { expenditures }\end{array}$ & PPS & $\begin{array}{l}\text { Refers to the social benefits transferred } \\
\text { to households that include different } \\
\text { functions as health care, old age, } \\
\text { disability, unemployment etc. }\end{array}$ & Eurostat \\
\hline GINI & percentage & $\begin{array}{l}\text { GINI coefficient is a measurement of the } \\
\text { income inequalities distribution within a } \\
\text { country, where } 0 \text { shows that there is } \\
\text { perfect equality and } 100 \text { shows perfect } \\
\text { inequality. }\end{array}$ & Eurostat \\
\hline NEET & percentage & $\begin{array}{l}\text { Refers to young people neither in } \\
\text { employment nor in education and } \\
\text { training and is calculated as a percentage } \\
\text { of young people aged } 15-24 \text { years. }\end{array}$ & Eurostat \\
\hline $\begin{array}{l}\text { Motorways } \\
\text { length }\end{array}$ & kilometers & $\begin{array}{l}\text { Represents the total lengths in kilometers } \\
\text { of the motorways in a specific country. }\end{array}$ & Eurostat \\
\hline $\begin{array}{l}\text { Passenger } \\
\text { Cars }\end{array}$ & $\begin{array}{l}\text { Per one } \\
\text { thousands } \\
\text { inhabitants }\end{array}$ & $\begin{array}{l}\text { Refers to the motorization rate calculated } \\
\text { as the ratio of the total number of cars of } \\
\text { a specific country divided by its } \\
\text { population. }\end{array}$ & Eurostat \\
\hline $\begin{array}{l}\text { Minimum } \\
\text { driving age }\end{array}$ & Value & $\begin{array}{l}\text { Refers to the minimum age of getting a } \\
\text { driving license in the EU countries. This } \\
\text { is a time-invariant variable since the } \\
\text { minimum driving age is the same for the } \\
\text { analysis period. }\end{array}$ & $\begin{array}{l}\text { The information was obtained from } \\
\text { https://www.rhinocarhire.com/Drive- } \\
\text { Smart-Blog/Minimum-Driving-Age- } \\
\text { Country.aspx\#minagecountry5 }\end{array}$ \\
\hline $\begin{array}{l}\text { Supervised } \\
\text { driving }\end{array}$ & $\begin{array}{l}\text { Dummy } \\
\text { variable }\end{array}$ & $\begin{array}{l}\text { For most of EU countries the minimum } \\
\text { driving age is } 18 \text { years but for some } \\
\text { countries can be smaller if the young } \\
\text { driver is supervised when driving (in } \\
\text { France from } 15 \text { years, in Sweden, } \\
\text { Slovenia, Netherlands, Iceland, Estonia, } \\
\text { from } 16 \text { years, and in Austria, Denmark, } \\
\text { Germany, Italy, Luxembourg, Slovakia } \\
\text { from } 17 \text { years). This is a time-invariant } \\
\text { variable and is denoted with } 1 \text { if the } \\
\text { country requires a supervised driving. }\end{array}$ & $\begin{array}{l}\text { The information was obtained from } \\
\text { https://www.rhinocarhire.com/Drive- } \\
\text { Smart-Blog/Minimum-Driving-Age- } \\
\text { Country.aspx\#minagecountry5 }\end{array}$ \\
\hline $\begin{array}{l}\text { Alcohol } \\
\text { legal limit } \\
\text { standard }\end{array}$ & Value & $\begin{array}{l}\text { This variable shows the value of the } \\
\text { maximum legal limit for drink driving. } \\
\text { In some countries, these limits are } \\
\text { different depending on the driver's } \\
\text { category. Thus three categories of } \\
\text { drivers can be differentiated: standard } \\
\text { (for all other types of drivers if they are } \\
\text { not commercial or novice), commercial, } \\
\text { and novice. }\end{array}$ & $\begin{array}{l}\text { The information was obtained from } \\
\text { https://etsc.eu/issues/drink- } \\
\text { driving/blood-alcohol-content-bac- } \\
\text { drink-driving-limits-across-europe/\# }\end{array}$ \\
\hline
\end{tabular}

PICBE | 230 
Due to the fact that the variables of interest are both fixed effects and time-invariant, the analysis employed the Arellano-Bover/Blundell-Bond linear dynamic panel-data estimation (StataCorp, 2015), based on a system generalized method of moments (Dynamic GMM), which is also suitable for datasets with few time observations (Drukker, 2008; Ahmad \& Khan, 2019). Except for the time-invariant variables, for all other variables the natural logarithm to ensure comparability of the results. Also, panel data models are the right approach when the statistical analysis is performed at the country level (Albalate et al., 2013).

The Arellano-Bover/Blundell-Bond linear dynamic panel-data estimation is described as a function of lagged dependent variable (Drukker, 2008):

$$
y_{j, t}=\alpha_{0 j} \cdot y_{i, t-1}+\sum_{i=1}^{m} \quad x_{i j, t} \cdot \beta_{i j}+\varepsilon_{j, t}
$$

Where:

$\mathbf{y}_{\mathbf{j} t}$ represents the dependent variable for country $\mathrm{j}(\mathrm{j}=1, \ldots, \mathrm{N}, \mathrm{N})$ and year $\mathrm{t}(\mathrm{t}=1, \ldots, \mathrm{T}, \mathrm{T})$; $\mathbf{x}_{i j t}$ represents the independent variable $\mathrm{i}(\mathrm{i}=1, \ldots, \mathrm{m})$ for country $\mathrm{j}$ and year $\mathrm{t}(\mathrm{t}=1, \ldots, \mathrm{T}, \mathrm{T})$; $\boldsymbol{\alpha}_{0}$ represents the intercept which is common for all countries; $\boldsymbol{\varepsilon}_{\mathbf{j t}}$ represents the error term.

Arellano-Bover/Blundell-Bond is an estimator designed for typical situations but the most important are that it can be used if the data set contains few time observations and the model may be affected by the presence of heteroscedasticity and autocorrelation within cross-sectional observations (Baum, 2014).

\section{Results and discussions}

This paper aims to observe if the road fatalities are somehow connected to road safety laws and some macroeconomic outputs of a particular country in the European Union. Considering that the time-span of the dataset is relatively small, the Arellano-Bover/Blundell-Bond estimator was applied. This type of estimation also brings the benefit of observing if the road fatalities in the European Union are a persistent phenomenon by including the lagged dependent variable.

For the purpose of the paper, the first estimation was made using all the variables of interest (see Model 1, table no. 2). The result shows that the variables Social expenditures, GINI coefficient, and passenger cars are not statistically significant and were removed from the analysis.

The final estimation contains only the significant variables (see Model 2, table no. 2). The results showed that the lagged rate of persons killed in car accidents has a negative influence on the rate of persons died in car accidents, confirming that in the EU the policies on road safety have contributed to reducing mortality due to car accidents (Albalate et al., 2013; European Commission, 2019).

The main risk factors related to road fatalities were the minimum driving age, supervised learning, and alcohol legal limit. In the case of the minimum driving age and supervised learning, there is a connection, mainly because if the minimum driving age will be lower, the driver has to learn under supervision. Thus, if the minimum driving age increases the road fatalities will increase by $29,8 \%$, but if the young driver is driving under supervision, the road fatalities will decrease by $48 \%$. This result shows how important it is for the future driver to form his driving experience under supervision. 
Table 2. Results from the developed models

\begin{tabular}{|l|l|l|}
\hline \multicolumn{1}{|c|}{ Variable } & \multicolumn{1}{c|}{ Model 1 } & \multicolumn{1}{c|}{ Model 2 } \\
\hline L.ln(Rate of persons killed in car accidents) & $-0.262(*)$ & $-0.236(*)$ \\
\hline $\ln ($ Social expenditures) & -0.069 & - \\
\hline $\ln ($ GINI) & 0.178 & - \\
\hline $\ln ($ NEET) & $0.277(* *)$ & $0.356(* *)$ \\
\hline $\ln ($ Motorways length) & $-0.145(* *)$ & $-0.136(* *)$ \\
\hline $\ln ($ Passenger Cars) & -0.127 & - \\
\hline Minimum driving age & $0.306(*)$ & $0.298(* *)$ \\
\hline Supervised driving & $-0.432(* *)$ & $-0.480(* *)$ \\
\hline Alcohol legal limit standard & $0.790(* *)$ & $0.560(* *)$ \\
\hline Wald chi2(df) & $117.15(* *)$ & $92.5(* *)$ \\
\hline Note: P-value in box parentheses; $*$ P-value $<0.10$ and $* * \mathrm{P}-\mathrm{value}<0.05$
\end{tabular}

PICBE | 232

Another significant result regarding the time-invariant variables is related to the legal alcohol limit, which has a positive impact on road fatalities, generating an increase of $56 \%$. Therefore, a higher blood alcohol limit leads to an increase in the number of traffic fatalities.

As expected, the length of motorways has a negative impact leading to a $13.6 \%$ decrease in the number of road fatalities. An interesting result arises for the variable NEET (young people neither in employment nor in education and training) which directly affects the road fatalities, so if the share of young people neither in employment nor in education and training increase would generate an increase of $0.36 \%$ in road fatalities.

\section{Conclusion and study limitations}

Traffic fatalities are still a significant public health issue, and most policy-makers are involved in their reduction and prevention (World Health Organization, 2009).

This study enriches the current literature from the perspective of macro-level analysis. One of the main limitations of this study is related to the few time observations involved in the investigation. Hence, the dataset covered a period of only seven years, from 2012 to 2018. Another limitation of this study is the lack of macroeconomic data regarding infrastructure investments, which may be a critical factor in determining the change in road fatalities.

Even though during the Covid-19 lockdown, some countries reported a significant decrease in road fatalities (European Transport Safety Council, Oscar et al., 2020), the solution is not to reduce mobility. Instead, a reappraisal of the road safety laws may be needed to reduce traffic fatalities. Limiting the alcohol consumption may be a solution especially considering that at the legal limit of $0.5 \mathrm{~g}$ per liter, the driver experiences a reduction in the visual field and immediate reaction capabilities.

Another key result is related to the length of the motorways, which leads to a higher value of road fatalities. Investing in highway construction should be a key factor for the policy-makers. In the end, besides policy implications, this paper highlights the importance of the educational system as one of the key variables NEET, which captures both education and the labor market, directly and significantly impacts road fatalities.

Future research should also include issues related to more road regulation, as it is essential to understand how it contributes to the changes in road fatalities. 


\section{References}

Ahmad, M., \& Khan, R. E. A. (2019). Does demographic transition with human capital dynamics matter for economic growth? A dynamic panel data approach to GMM. Social Indicators Research, 142(2), 753-772, https://doi.org/10.1007/s11205-018-1928-x.

Albalate, D., Fernández, L., \& Yarygina, A. (2013). The road against fatalities: Infrastructure spending vs. regulation?, Accident Analysis \& Prevention, 59, 227-239.

Baum, C.F. (2014). Dynamic Panel Data estimators, EC 823, Applied Econometrics, Boston College, https://fmwww.bc.edu/EC-C/S2014/823/EC823.S2014.nn05.slides.pdf.

Benson, B. L., Rasmussen, D. W., \& Mast, B. D. (1999). Deterring drunk driving fatalities: an economics of crime perspective, International review of law and economics, 19(2), 205-225.

Drukker, D. M. (2008, July). Econometric analysis of dynamic panel-data models using Stata. In Summer North American Stata Users Group meeting, 24-25.

Edwards, J. B. (1998). The relationship between road accident severity and recorded weather. Journal of Safety Research, 29(4), 249-262.

European Commison (2019). 2019 road safety statistics: what is behind the figures? https://ec.europa.eu/commission/presscorner/detail/en/QANDA_20_1004.

European Transport Safety Council (2020). Briefingthe Impact of Covid-19 Lockdowns on Road Deaths in April 2020 July.

Kopits, E., \& Cropper, M. (2003). Traffic fatalities and economic growth. The World Bank.

Ghadi, M., Török, Á., \& Tánczos, K. (2018). Study of the economic cost of road accidents in Jordan. Periodica Polytechnica Transportation Engineering, 46(3), 129-134.

Hamed Al-Reesi, Shyam Sunder Ganguly, Samir Al-Adawi, Lucie Laflamme, Marie Hasselberg \& Abdullah Al-Maniri (2013) Economic Growth, Motorization, and Road Traffic Injuries in the Sultanate of Oman, 1985-2009, Traffic Injury Prevention, 14:3, 322-328, DOI: 10.1080/15389588.2012.694088.

Mann, R. E., Zalcman, R. F., Asbridge, M., Suurvali, H., \& Giesbrecht, N. (2006). Drinking-driving fatalities and consumption of beer, wine and spirits, Drug and Alcohol Review, 25(4), 321-325.

Missoni E, Mlinarić-Vrbica S, Meschino M, Pancrazi E (2018). Alcohol Related Crashes in Europe. J J Alcohol Drug Depend Subst Abus 4: 008.

Òscar, S., Edgar, B., Aaron, G. (2020). COVID-19 lockdown and reduction of traffic accidents in Tarragona province, Spain, Transportation Research Interdisciplinary Perspectives, Volume 8, https://doi.org/10.1016/j.trip.2020.100218.

Papalimperi, A. H., Athanaselis, S. A., Mina, A. D., Papoutsis, I. I., Spiliopoulou, C. A., \& Papadodima, S. A. (2019). Incidence of fatalities of road traffic accidents associated with alcohol consumption and the use of psychoactive drugs: A 7-year survey (2011-2017). Experimental and therapeutic medicine, 18(3), 2299-2306.

Roşca, V. I. (2019). Costs a pretty penny: how household income impacts upon motorization in Europe and raises manufacturer branding challenges, Proceedings of the International Conference on Business Excellence, 13(1), 759-771, doi: https://doi.org/10.2478/picbe2019-0067.

StataCorp, L. P. (2015). Stata treatment-effects reference manual. College Station, TX: A Stata Press Publication.

SafetyNet (2009) Alcohol, retrieved 16 January 2021. 
Thomas, P., Morris, A., Talbot, R., \& Fagerlind, H. (2013). Identifying the causes of road crashes in Europe. Annals of advances in automotive medicine, 57, 13.

WHO Regional Office for Europe, (2009). European status report on road safety: towards safer roads and healthier transport choices. Copenhagen.

Yannis G., Antoniou, C., Papadimitriou, E., Katsochis, D. (2011). When may road fatalities start to decrease?, Journal of Safety Research, 42(1), 17-25, ISSN 0022-4375, https://doi.org/ 10.1016/j.jsr.2010.11.003.

PICBE |

Young, D. J., \& Likens, T. W. (2000). Alcohol regulation and auto fatalities, International Review of Law and Economics, 20(1), 107-126. 